\title{
Corporate Diversification And Firm Performance Impact On Chief Executive Officers Salary
}

\author{
Hwei Cheng Wang, University of Maryland Eastern Shore, USA \\ Howard Lawrence, University of Mississippi, USA \\ Chia-Hui Chen, Providence University, Taiwan
}

\begin{abstract}
The purpose of this research is to examine CEO salary and to explore whether the independent variables (international diversification, industrial diversification, market-based performance, accounting-based performance) are associated with CEO salary. Corporate diversification in this study is divided into international diversification and industrial diversification. Data for the study was obtained from annual reports of CEO salary on the ExecuComp database. Compensation data collected from the annual reports encompassed 2,448 CEOs from 1,622 firms. The dependent variable was developed from a review of CEO salary and accounting literature. The hypothesized predictors of CEO salary were identified through a review of existing studies. The results show that the higher the degree of international diversification and/or industrial diversification, the more CEOs receive in fixed salary. In addition, this study found that CEO salary is a better predictor of accounting performance than stock return performance.
\end{abstract}

Keywords: CEO Compensation; Chief Executive Officer Salary; Corporate Diversification; International Diversification; Industrial Diversification; Firm Performance

\section{INTRODUCTION}

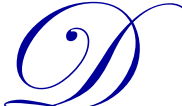

uring the past decade, CEO compensation has drawn considerable public scrutiny (Cyert, Kang, \& Kumar, 2002) with many researchers examining the relationship between CEO compensation and corporate governance mechanisms (Cyert, Kang \& Kumar, 2002; Sanders \& Carpenter, 1998). Moreover, a growing number of researchers have found a link between incentive compensation and performance (Kaplan, 1994; Jensen \& Murphy, 1990). Research has shown that CEOs of growth firms receive a larger portion of their compensation from long-term incentive compensation, while those of non-growth firms receive a larger portion of their pay from fixed salary. However, few researchers have analyzed CEO salary. Thus, in order to find the factors that impact on CEO salary, this study uses International Diversification, Industrial Diversification, Market Based Measures of Performance, Accounting Based Measures of Performance, Investment Opportunities, Firm Size, and Stock ownership as the determinants of Chief Executive Officer Salary. Control variables for the study are Tenure, Age, Duality, and Gender.
\end{abstract}

\section{Definition of Terms}

\section{Executive Compensation}

The U.S. Securities and Exchange Commission (SEC) requires listed firms to report certain information on the compensation of their five most highly paid executives, which typically includes among others, the Chief Executive Officer (CEO). Numerous researchers have developed their own definitions of executive compensation based on their sample data. Gaver and Gaver (1995), for example, state that total compensation equals base salary plus annual bonus plus long-term compensation. Duru and Reeb (2002), on the other hand, considered total 
compensation to be the sum of short-term compensation and long-term compensation. Short-term compensation included salary and cash bonus. Long-term compensation included stock options, restricted stocks and miscellaneous other long-term compensation. Standard and Poors Research Insight (2004) state that total compensation is comprised of salary, bonus, other annual compensation, total value of restricted stocks granted, total value of stock options granted (using Black-Scholes method), long-term incentive payouts, and all other total compensation.

\section{Corporate Diversification}

Corporate diversification consists of both international diversification and industrial diversification (Duru \& Reeb, 2002; Kim, Kim, \& Pantzalis, 2001).

\section{International diversification}

International diversification is defined as a firm's expansion beyond the borders of its domestic country across different countries and geographical regions (Capar \& Kotabe, 2003).

\section{Industrial Diversification}

Industrial diversification is the expansion of a company into different lines of business or industry segments (Kim, Kim, \& Pantzalis, 2001).

\section{Definitions in this study}

For purposes of this study, the following definitions apply:

Table 1

\begin{tabular}{ll}
\hline Term & Definition \\
\hline Total Compensation & Short-term compensation plus long-term compensation plus all other compensation \\
\hline Short-term Compensation & Current compensation and other annual compensation \\
\hline Current Compensation & Annual salary and bonus \\
\hline Salary & $\begin{array}{l}\text { Dollar value of the base salary (cash and non-cash) earned by the named executive officer } \\
\text { during the fiscal year }\end{array}$ \\
\hline Bonus & $\begin{array}{l}\text { Dollar value of any bonuses (cash and non-cash) earned by the named executive officer } \\
\text { during the fiscal year }\end{array}$ \\
\hline Other Annual Compensation & Dollar value of other annual compensation not properly categorized as salary or bonus \\
\hline Long Term Compensation & Incentive compensation plans and all other compensation \\
\hline Incentive compensation plans & Stock options, restricted stocks and long-term incentive plans \\
\hline Stock Options & $\begin{array}{l}\text { The aggregate value of all options granted to the executive during the year as valued by } \\
\text { the company }\end{array}$ \\
\hline Restricted Stock & Value of all options granted during the year (determined as of the grant date) \\
\hline Long term Incentive Plans & Amount paid to the executive under the company's long-term incentive plan \\
\hline All Other Compensation & Compensation not belonging under types of compensation \\
\hline Sources: Extracted from Duru and Reb (2002); Gaver and Gaver (2003); Sanders and Carpenter (1998) and Standard and Poors
\end{tabular}

Sources: Extracted from Duru and Reeb (2002); Gaver and Gaver (2003); Sanders and Carpenter (1998) and Standard and Poors Research Insight (2004).

\section{LITERATURE REVIEW AND HYPOTHESES DEVELOPMENT}

\section{International Diversification and CEO salary}

International operations are more profitable than comparable domestic operations (Fatemi, 1984). When corporations diversify internationally, operations result in a more complex managerial decision-making environment (Duru \& Reeb, 2002). International diversification also requires enhanced information processing and requires specialized knowledge of competitor operations as well as the firm's own operations across boundaries (Sanders \& Carpenter, 1998). The increased complexity of international operations increase the shareholders and board of 
directors difficulty of monitoring the CEO, thereby better aligning CEO interests with stockholder interests and thus increasing CEO salary. In order to reduce the shareholders and board of directors' difficulty of monitoring the CEO, a variety of motivation strategies based on expectancy theory were used to increase performance in decision-making that were consistent with shareholder wealth maximization. A measurement was made to determine if the performance improved and the expected compensation reward was produced. Thus, this study predicts that international diversification is positively associated with CEO salary. Therefore:

Hypothesis $H_{1}$ : International diversification is positively associated with CEO salary.

\section{Industrial Diversification and CEO salary}

Corporate diversification into different industries creates a portfolio of operational units (Kim, Kim \& Pantzalis, 2001). Industrial diversification potentially benefits corporate managers through increased power and salary (Denis, Densi \& Yost, 2002). Based on expectancy theory, an increase in the CEO salary will motivate managers to work harder on these more complex operational units to increase performance and to make decisions that are consistent with shareholder wealth maximization. Therefore:

Hypothesis $H_{2}$ : Industrial diversification is positively associated with CEO salary.

\section{Firm Performance and CEO salary}

Researchers (Duru \& Reeb, 2002; Balkin, Markman, \& Gomez-Mejia, 2000) have indicated that companies in different industries are likely to have different measures of company performance. Two types of company performance measures are the accounting based measure of performance and the market based measure of performance. Sanders and Carpenter (1998) point out those firms with high levels of performance may be able to pay more compensation than those that are performing less well. Consistent with prior research, the accountingbased measure of performance for this study is defined as annual earnings before interest and taxes (EBIT) whereas the market-based measure of performance is defined as the common stock return at the end of the fiscal year. Expectancy theory implies that higher CEO salary will have a higher motivational effect on the CEO, and this higher motivation will result in higher firm performance thus maximizing shareholder wealth.

\section{Market Based Measures of Performance}

Market-based measures of performance often center on some measure of the price of a single share of a company's outstanding stock and stock return. Accordingly, stock performance is usually measured by changes in stock prices or stock return. Therefore, firms in industries that experience rapid growth, or involve rapid product cycles, may benefit from aligning their executives' CEO salary with market-based measures of performance (Grossman \& Hoskisson, 1998).

\section{Accounting Based Measures of Performance}

Accounting-based performance measures are incrementally useful over market-based measures in CEO compensation contracts (Duru \& Reeb, 2002; Baber et al., 1996). In an accounting-based measure of company performance, researchers typically use profitability or some measure of stockholders' equity (Tosi \& Gomez-Mejia, 1994). Profitability is usually measured as earnings per share (EPS), return on assets (ROA) earnings before interest and taxes (EBIT) and/or return on equity (ROE). The measures of EBIT, ROE and ROA are easily determined, perceived to be objective, and widely understood by owners and managers alike (Grossman \& Hoskisson, 1998). According to Pavlik, Scott and Tiessen (1993), accounting performance is more important than stock performance with respect to cash compensation. Financial ratios are widely used in accounting-based measures in firm performance. Some researchers have relied on an internal performance measure, such as profit (Deckop, 1988), or ROE (Redling, 1981), or change in shareholder return (Platt, 1987), or a combination of nine measures of performance, including sales, profit, ROE, and EPS (Gomez-Mejia et al., 1987). 
Previous empirical evidence also suggests that accounting-based, performance measures are incrementally useful over market-based, measures in executive compensation contracts (Duru \& Reeb, 2002; Baber, Janakiraman, \& Kang, 1996). When accounting returns are less informative with respect to the executive's actions, there is a greater reliance on market-based measures than on accounting-based measures (Bryan, Hwang, \& Lilien, 2000). Executives have discretion in choosing among various accounting or reporting alternatives that can be used to manipulate accounting earnings. Because of the ability and incentive of executives to arbitrage differing accounting and tax regimes, international settings have a higher likelihood of earnings manipulation, than domestic settings (Duru \& Reeb, 2002). Moreover, the potential for imperfect hedging on foreign exchange exposure suggests that accounting-based, performances measures are more useful than market-based performance measures when there is international diversification (Duru \& Reeb, 2002).

Expectancy theory suggests that high salary compensation can be an effective strategy to motivate CEOs performance in a manner that is consistent with shareholder wealth maximization. Therefore,

Hypothesis $H_{3}$ : Market-based performance is positively associated with CEO salary.

Hypothesis $H_{4}$ : Accounting-based performance is positively associated with CEO salary.

\section{Accounting-based performance measures, Market-based performance measures and CEO salary}

Pavlik, Scott, and Tiessen (1993) found that accounting performance is more important than stock performance with respect to cash compensation. This was especially true if the compensation consisted of some level of stock options. Singh and Agarwal (2002) found that short-term compensation is better predicted by accounting-based performance measures than by market-based performance measures. In addition, Gaver and Gaver (1995) found that CEOs of growth firms receive a larger portion of their compensation from long-term incentive compensation whereas, those of non-growth firms receive a larger portion of their pay from fixed salary. Moreover, prior studies have shown that accounting earnings play a significant role in measuring performance for the purpose of compensation (Jensen \& Murphy, 1990). Thus, this study argues that CEO salary is predicted by accounting-based performance measures than by market-based performance measures. Therefore:

Hypothesis $H_{5}$ : CEO salary is better predicted by accounting-based performance measures than by market-based performance measures.

\section{METHODOLOGY}

\section{Measurement}

\section{The Compensation Model}

A regression model was developed to test the hypotheses. The compensation function discussed in the next section is modeled as:

CEO compensation structure ${ }_{i}=\mathrm{f}$ (INTD, INDD, RET, ACE, IO, SIZE, OWN, Tenure, Age, Duality, Gender)

Where CEO compensation structure $=$ CEO salary

INTD = International Diversification

INDD $=$ Industrial Diversification

RET $=$ Market-based measure of performance

$\mathrm{ACE}=$ Accounting-based measure of performance

$\mathrm{IO}=$ Investment Opportunities

SIZE $=$ Firm Size

OWN= Stock Ownership

Tenure $=\mathrm{CEO}$ position tenure 
Age $=\mathrm{CEO}$ age

Duality $=\mathrm{CEO}$ duality

Gender $=\mathrm{CEO}$ gender

Dependent variables database.

The dependent variable in this model is CEO salary. CEO salaries were obtained from the ExecuComp

$C E O$ salary $=$ SALARY

Salary is the dollar value of the base salary (cash and non-cash) earned by the named executive officer during the fiscal year.

Independent Variables

The independent variables are listed below. Data for the independent variables were obtained from COMPUSTAT's Geographic Segment File, COMPUSTAT's Industry Segment File, COMPUSTAT's database, and the CRSP database.

$\underline{\text { International Diversification (INTD) }}$

Firms are classified as multinational if they report any foreign sales on COMPUSTAT's Geographic Segment File. Otherwise, they are classified as domestic firms. COMPUSTAT limits the number of global segments to five.

$\underline{\text { Industrial Diversification (INDD) }}$

Firms are classified as multi-segment on COMPUSTAT's Industry Segment File if they report more than one business segment on COMPUSTAT's Industry Segment File. Otherwise, they are classified as single-segment. COMPUSTAT limits the number of industrial segments to 10 .

Firm performance (FP)

Market-based performance (RET) is measured as the common stock return at the end of the fiscal year. Accounting-based performance (ACE) is measured as annual earnings before interest and taxes (EBIT). Marketbased, measures of performance are often centered on some measure of the price of a single share of a company's outstanding stock and stock return. Stock performance is usually measured by changes in stock prices or stock return. The advantages of market-based measures of performance are that they are easily determined, objective, and widely understood by both owners and managers (Grossman \& Hoskisson, 1998). Compared to market-based measures of performance, accounting-based performance measures are considered by some researchers to be incrementally useful for CEO salary contracts (Duru \& Reeb, 2002; Baber et al., 1996) Accounting-based, measures of company performance usually rely on profitability or stockholders equity (Tosi \& Gomez-Mejia, 1994). Profitability is usually measured as EPS, ROA, or EBIT. Return on assets (ROA) is used to measure the performance of each individual year within the sample in this study.

\section{Control Variables}

The control variables for this study are Investment Opportunities, Firm Size, Stock Ownership, CEO position tenure, age, duality, and gender. 
$\underline{\text { Investment Opportunity (IO) }}$

Investment opportunity (IO) is defined as research and development expenditures divided by the market value of the firm. The literature contains several measures for the firm's IOs (Collins, Blackwell \& Sinkey, 1995). The investment opportunity set is unobservable and determining is likely to be imperfectly measured by any individual measure. The most frequently used measures of investment opportunity are market-to-book ratios, such as the ratio of the market value of the firm to the book value of its assets (Duru \& Reeb, 2002; Gaver \& Gaver, 1993). A factor analysis was conducted to form a composite measure of the investment opportunity set using prior investment intensity, growth in the market value of assets, market-to-book ratio, and research and development expenditures (R\&D). Another popular measure of investment opportunity is the ratio of the market value of equity to the book value of equity (Chung \& Charoenwong, 1991). The level of R\&D intensity is also another measure of the investment opportunity set (Kole, 1994; Skinner, 1993). Revenue or return variability have also been used as measures of investment opportunity (Christie, 1995; Smith \& Watts, 1992). Growth firms can be expected to have high market-to-book asset and equity ratios, levels of research intensity, and variability measures.

Lambert and Larcker (1987) employed the growth rate in assets as a measure for the size of the investment opportunity set. They argued that regulated firms have a smaller investment opportunity set than larger firms. Moreover, Smith and Watts (1984) utilized a binary variable to determine whether a firm operates in a regulated industry. In addition, Lehn and Poulsen (1989) used the growth rate in sales to measure the investment opportunity set for firms going private. Collins, Blackwell and Sinkey (1995) employed three different measures of investment opportunity set. They used the ratio of the market value of common equity to the book value of common equity (MKT/BOOK). The market value of equity reflects the investors' ownership in the market value of assets-in-place plus the market value of growth options while the book value of equity reflects the investors' ownership in the existing assets of the firm. The MKT/BOOK ratio, therefore, should be higher for firms with greater growth opportunities. To measure investment opportunities, this study uses research and development expenditures divided by the market value of the firm (Gaver \& Gaver 1993; Baber, Janakiraman \& Kang, 1996).

\section{$\underline{\text { Firm Size (SIZE) }}$}

Firm size in this study is measured as total assets. Sales volume (Newman \& Banister, 1998) and total assets (Sridharan, 1996; Useng, 2000) are two generally used measured of firm size. Firm size is positively associated with the level of executive compensation (Sanders, Carpenter, 1998; Finkelstein \& Hambrick, 1996; Gaver \& Gaver, 1995; Geomez-Mejia, 1994). Higher levels of compensation are expected to be paid to executives in larger firms (Gaver \& Gaver, 1995) because the larger the scope of operations, the greater the demands on top executives. Useng, Wells, and Lilly (2000) examined the determinants of CEO pay for small and large firms and determined that firm size is a primary factor in determining CEO pay within small firms. This study uses firm size (SIZE) as a moderator variable. It is also used as an independent variable in the study's models.

\section{Stock Ownership (OWN)}

CEO stock ownership (OWN) is strongly related to compensation (Cyert, Kang \& Kumar, 2002; Sanders \& Carpenter, 1998). The level of a CEO's stock ownership is associated with the proportion of pay helshe receives in long-term forms (Sanders \& Carpenter, 1998). Sanders \& Carpenter (1998) expressed CEO ownership as the percent of total outstanding shares. In addition, Sanders and Carpenter (1998) measured CEO stock ownership as the value of outstanding common shares owned by the CEO. As the measure for CEO stock ownership, this study uses the percentage of the company's shares owned by the named executive officer. Data were collected from Standard \& Poor's COMPUSTAT ExecuComp database. This study uses stock ownership (OWN) as a moderator variable. It is also used as an independent variable in the study's models.

\section{$\underline{\text { Tenure }}$}

Tenure is measured as the number of years the executive has served as CEO. Studies have shown that the CEO's position tenure affects CEO compensation (Cyert, Kang \& Kumar, 2002). Executives with short tenures are generally likely to take more risks as decision makers and to depart from historical conventions than are long- 
tenured executives (Sanders, 2001). Longer tenure increases the CEO's power, enabling him her to effectively increase their pay for performance (Hill \& Phan, 1991). Sanders and Carpenter (1998) found that a CEO's position tenure is positively associated with level of compensation. Young and Buchholtz (2002) found increased dissimilarity in tenure to be associated with a stronger pay-performance relationship. This study measures CEOs' position tenure as the number of years that the CEO has held his or her current position. Data were collected from Standard \& Poor's COMPUSTAT ExecuComp database.

$\underline{\text { Age }}$

Age is measured as the age of the CEO at the end of the fiscal year. CEO age has been shown to be positively associated with base salary and equity compensation (Cyert, Kang \& Kumar, 2002). CEO age affects his her attitude towards employment. Mature CEOs are more conservative in their decision-making than younger CEOs (Wiersema \& Bantel, 1992), and Lewellen, Loderer and Martin (1987) argue that a CEO's age is associated with a CEO's compensation and firm performance. In addition, CEO age is strongly related to CEO strategic choices (Hambrick \& Mason, 1984), and Hitt and Barr (1989) found that CEO age is associated with compensation decisions. If a CEO is nearing retirement and is a principal owner helshe may pay himselflherself a lower salary to enhance future capital gains when they retire and transfer ownership (Cooley \&Edwards, 1982). The CEO may also defer income into the future to prevent a higher tax rate. Data for age were collected from Standard \& Poor's COMPUSTAT ExecuComp database.

\section{Duality}

Duality means that a CEO holds both the CEO position and chairperson of the board position. CEO duality is measured as a dummy variable with a CEO holding both positions being coded with a 1 and one not holding both positions being coded as a 0 .

The primary function of the chairperson is to organize board meetings and to take a lead in hiring, terminating, and compensating the CEO. A combined role of CEO and chairperson involves a potential conflict of interest in carrying out these separate roles and many feel it is important to separate the chairperson and CEO positions for the board to operate effectively. Thus, CEO duality has a negative relationship with effective board control. CEO compensation is expected to be higher in companies if duality exists, and it is expected that board control of the management decision function is lower in the presence of CEO duality. In addition, in complex environments where there is a high International diversification and industry diversification, duality is strongly related to CEO salary (Sanders \& Carpenter, 1998). Moreover, Cyert, Kang and Kumar (2002) found CEO duality to be positively related to CEO compensation. Young and Buchholtz (2002) found that duality has a significant effect on the change in CEO pay, in that CEOs who are also board chairs receive higher pay. CEO duality is positive in the sense that it gives CEO's the authority and responsibility to support effective decision-making (Finkelstein \& D'Aveni, 1994), and they are able to respond more quickly to complex environments (Boyd, 1994). Therefore, compensation committees can reasonably expect more from dual-titled CEOs and can tie CEO salary more closely to performance. Data for duality were collected from Standard \& Poor's COMPUSTAT ExecuComp database.

\section{$\underline{\text { Gender }}$}

Gender is measured as a dummy variable. If the CEO's gender is male, a 1 is coded. If the CEO is female, a 0 is coded. Popular press articles show that there is a gender component to CEO compensation and several authors have previously examined gender pay differences among the highly paid (Barbezat \& Hughes, 1990; Gander, 1997; Ransom \& Megdal, 1993). Few studies have addressed gender compensation paid (Bertrand \& Hallo, 2000) and the results are inconclusive due to differing sample sizes (Bertrand \& Hallo, 2000). Therefore, it is important to explore whether gender has a significant impact on compensation.

Bertrand and Hallo (2000) analyzed gender differences among top executives in a large set of U.S. public corporations. They examined the gender compensation gap among high-level executives for the period 1992-1997 by using Standard and Poor's ExecuComp data sample of more than 42,000 executive-year observations. The results indicated that, between 1992 and 1997, women nearly tripled their participation in the top executive ranks and 
strongly improved their relative compensation. The gender gap in compensation among top executives was at least 45\% in 1997. Mohan and Ruggiero (2003) examined the compensation level for 47 female CEOs who held office during 2000 and compared their pay to a matched sample of firms headed by male CEOs. All components of their compensation were considered, including cash salary, bonus, long-term incentives, and the value of options granted for fiscal year 2000. The results supported the popular press articles that there is a gender component to CEO compensation. Williams (2003) found that men and women have consistent inequities in compensation. For the CEO position, he found that women earned an annual median total compensation of $\$ 98,000$ compared to the $\$ 147,000$ earned by men. Data for gender were collected from Standard \& Poor's COMPUSTAT ExecuComp database.

\section{Sample Selection and Data Collection}

The sample for this study was derived from secondary data selected from three databases, and supplemented with Security and Exchange Commission (SEC) data. To be included in the sample, this study required that the company's stock return data were available from the Center in Research in Security Prices (CRSP) and that financial statement data be available from Standard and Poors ' Research Insight. The ExecuComp database is based on the $\underline{S \& P} 400, \underline{S \& P} 500$, and $\underline{S \& P} 600$ indexes that comprise mid-, large-, and small-cap firms, respectively. This database reduces the time investment required to extract data from proxy statements, and alleviates the difficulty of extracting specific information from individual company reports. However, there is often missing data, particularly relating to age and employment starting dates. Thus, it was necessary to supplement information in the ExecuComp database with information contained in Lexis/Nexis.

Table 2. Data Sources

\begin{tabular}{ll}
\hline Variables & Source of Data \\
\hline Dependent Variables & Standard \& Poor's COMPUSTAT ExecuComp database \\
\hline CEO salary & \\
\hline Independent Variables & \\
\hline International Diversification(INTD) & COMPUSTAT's Geographic Segment File \\
Industrial Diversification(INDD) & COMPUSTAT's Industry Segment File \\
Market based Performance(RET) & CRSP Database \\
Accounting based Performance(EBIT) & COMPUSTAT Database \\
& \\
\hline Control Variables & \\
\hline Investment Opportunities & COMPUSTAT Database \\
Firm Size (SIZE) & COMPUSTAT Database \\
Stock Ownership (OWN) & COMPUSTAT and ExecuComp Database \\
Tenure & Standard \& Poor's COMPUSTAT ExecuComp database \\
Age & Standard \& Poor's COMPUSTAT ExecuComp database \\
Duality & Standard \& Poor's COMPUSTAT ExecuComp database \\
Gender & Standard \& Poor's COMPUSTAT ExecuComp database \\
\hline
\end{tabular}

CEO salary data were obtained from Standard \& Poor's COMPUSTAT ExecuComp (1997-2002). Most studies of CEO salary rely upon secondary data from filings with the Securities and Exchange Commission (SEC) (Miller, 1995). International diversification data were obtained from COMPUSTAT's Geographic Segment File. Firms were classified as multinational, if firms report any foreign sales on COMPUSTAT's Geographic Segment File; otherwise, they were classified as domestic firms. COMPUSTAT limits the number of global segments to five. Industrial diversification data were obtained from COMPUSTAT's Industry Segment File. Firms were classified as multi-segment on COMPUSTAT's Industry Segment File if they report more than one business segment on COMPUSTAT's Industry Segment File; otherwise, they were classified as single-segment. COMPUSTAT limits the number of industrial segments to 10. In each year from 1997 to 2002, all firms that had data on both the Industry Segment and the Geographic Segment tapes were identified. Market-based, data on firm performance for excess stock return data were from the CRSP database. Finally, the financial characteristic data and accounting-based, data on firm performance were from the COMPUSTAT database. These secondary data were considered to provide dependable and reliable data; thus, the data on the corporations for this study were obtained from these sources. The source of data is summarized in Table 2. 
This study classified each firm's primary Standard Industrial Classification (SIC) Code according to the 10$\mathrm{K}$ product breakdown (SIC), and classified each firm according to the industry classification scheme suggested by Lippert and Moore (1995) and further modified in this study. A list of the 2448 CEOs, industry classes and the SIC codes in this study are provided in Table 4.

Murphy (1985) implemented a similar sample selection criterion in his study. He used a time-series study of corporate performance and managerial compensation and included the top CEO only if the CEO was listed in the firm's financial statement during the period 1964 to 1970 and remained with the same firm for at least five years. The sample selection for this study was conducted in a manner consistent with previous research on CEO compensation (Miller, 1995). For this study, 1622 firms or 2448 CEOs during year 1997-2002 were identified.

\section{Statistical Analysis}

\section{Descriptive Statistics}

In this study CEO salary is the dependent variable and international diversification, industrial diversification, accounting-based performance, and market-based performance are the independent variables. These statistics allow researchers to see the distribution of each variable.

\section{Statistics Used to Show Relationships}

Coefficient alpha, a type of internal consistency analysis, was conducted on the data to index the relationships among corporate differsification diversification, firm performance and CEO salary. Correlation analysis, in conjunction with multiple regression analysis, was utilized to gauge the strength of the relationships between corporate diversification, firm performance and CEO salary. Additionally, correlation coefficients (r) were used to measure the extent of the relationships between variables.

The correlation coefficient for examining the relationship between independent variables in this study is the Pearson Correlation coefficient. Squaring the correlation coefficient results in the coefficient of multiple determination $\left(R^{2}\right)$, which was used in this study to measure the percentage of the variability in the dependent variable that can be explained by the independent variable. Multiple regression analyses were employed to examine the relationship between corporate differsification diversification, firm performance and CEO salary. The purposes of these regression analyses are to answer the research questions in this study.

Regression analysis is the most widely utilized and versatile dependence technique applicable in the financial economics literature. Zajac and Westphal (2004) have noted that several authors such as McWilliams and Siegel (1997) have also advocated the use of multiple regression analysis to control for possible third variables. The Sample Data for this study covered six different periods, thus, autocorrelation could have occurred in the data (Binder, 1998). The objective of multiple regression analysis is to use predictor variables with known values to predict a dependent variable. Since the variables are weighted, their relative contribution to the prediction can be determined.

Multiple regressions were developed for the independent variable. The first step required in multiple regression is to identify the relationships that exist between the dependent and independent variables and the relationships that exist between the independent variables. This was done with correlation coefficients for every possible pair of variables in the analysis. The correlation matrices determined whether multicollinearity was evident. Multicollinearity exists when the independent variables are too highly correlated among themselves (Hanke $\&$ Reitsch, 1994). It was necessary to remove the variable with the least predictive explanatory power. The other reason to eliminate multicollinearity is that each of the independent variables should explain a different part of the dependent variable. The information output from these regressions was used to plot scatter diagrams for each variable to depict the relationship between variables. 
Multiple Regression Model

Multiple regression models were established to identify the determinants of CEO salary. CEO salary was selected as the dependent variable $(\mathrm{Y})$ to be predicted by the independent variables, control variables.

The first series of regression analyses tested the relationship between corporate diversification and CEO salary. These regression equations are as follows:

$$
\begin{aligned}
& S A L A R Y_{t, i}=b_{0}+b_{1} I N T D+b_{2} I N D D+b_{3} R E T+b_{4} A C E+b_{5} I O+b_{6} S I Z E+ \\
& b_{7} O W N+b_{8} \text { Tenure }+b_{9} \text { Age }+b_{10} \text { Duality }+b_{11} \text { Gender }+\varepsilon_{t, i}
\end{aligned}
$$

Where, $b_{0}=$ the constant of regression equation model 1

$b_{1}, b_{2}, b_{3}, b_{4}, b_{5}, b_{6}, b_{7}, b_{8}, b_{9}, b_{10}, b_{11}=$ coefficient of

INTD, INDD, RET , ACE, IO, SIZE, OWN, Tenure, Age, Duality, Gender

$S A L A R Y$ denotes CEO salary for firm $i$ at time period $t$; it is a dependent variable in equation 1.

INTD denotes international diversification.

INDD denotes industrial diversification.

$A C E$ denotes accounting-based performance and is measured by annual earnings before interest and taxes (EBIT).

$R E T$ denotes market-based performance and is measured by the common stock return at the end of the fiscal year.

$I O$ denotes investment opportunities and is measured by $\mathrm{R} \& \mathrm{D}$ expenditures scaled by the market value of the firm.

SIZE denotes firm size and is measured by total assets.

$O W N$ denotes stock ownership and is measured by the percentage of the company's shares owned by the named CEO officer.

Tenure denotes CEO's tenure and is the number of years that the CEO had held his/her current position at the end of the fiscal year.

Age denotes CEO's age and is the age of the CEO at the end of the fiscal year

Duality denotes CEO's duality and refers to the situation in which a CEO holds both the CEO and chairperson of the board positions.

Gender denotes CEO's gender and is the proxy gender of CEO, dummy variables, $1=$ male; $0=$ female

$\varepsilon_{t, i}$ is the error term (all measured for firm $i$ at time period $t$ ).

\section{ANALYSIS AND PRESENTATION OF FINDING}

\section{The Sampling}

The initial sample consists of 2,598 CEOs reported by the ExecuComp database for the six-year period from 1997-2002. From this initial sample, firms were excluded if they did not meet the following criteria: (1) Compensation data must be available on ExecuComp database, (2) Data must be available on Compustat's Geographic and Industry Segment File, (3) Financial data must be available on COMPUSTAT (Standard \& Poor's Research Insight), (4) Stock return data must be available in the files of the Center for Research on Security Prices (CRSP) database. Data on CEOs in this study consisted of the average of each variable for the CEOs.

The final sample in this study included 2448 CEOs in 1622 firms. Table 3 summarizes the number of firms that were excluded from the three databases. A breakdown of the 2448 CEOs by industry class and SIC code is provided in Table 4. 
Table 3

Reasons for elimination of CEO compensation firms from the initial sample

\begin{tabular}{|l|c|}
\hline Initial CEO sample & 2598 \\
\hline Data unavailable on ExecuComp database & 290 \\
\hline Data unavailable on Compustat's Geographic and Industry Segment File & 653 \\
\hline Data unavailable on COMPUSTAT database & 4 \\
\hline Data unavailable on CRSP database & 39 \\
\hline Final Sample & 1622 \\
\hline
\end{tabular}

Note. Data are comprised of 1,622 firms of observations from 1997-2002.

Table 4

Frequency statistics for CEOs $(\mathrm{N}=\mathbf{2 4 4 8})$

\begin{tabular}{|c|c|c|c|}
\hline & SIC codes & $\begin{array}{c}\text { Number of } \\
\text { observations }\end{array}$ & $\%$ \\
\hline \multicolumn{4}{|l|}{ Panel A: Filing Year } \\
\hline 1997 & & 335 & 14 \\
\hline 1998 & & 414 & 17 \\
\hline 1999 & & 828 & 33 \\
\hline 2000 & & 438 & 18 \\
\hline 2001 & & 433 & 15 \\
\hline 2002 & & 71 & 3 \\
\hline Total & & 2448 & 100.0 \\
\hline \multicolumn{4}{|l|}{ Panel B: Type of Industry (SIC) } \\
\hline $0=$ aerospace and shipbuilding & $3720-3829$ & 96 & 3.9 \\
\hline $1=$ agriculture and metal & 0000-1099, 1400-1499 & 34 & 1.4 \\
\hline $2=$ cars & $3711-3716$ & 42 & 1.7 \\
\hline $3=$ chemical, tire, and leather & $2800-2821,3011-3199$ & 73 & 3.0 \\
\hline $4=$ commodity & $4812-4899$ & 47 & 1.9 \\
\hline $5=$ computer and software & $3570-3579,7370-7389$ & 299 & 12.2 \\
\hline $6=$ construction, wood, furniture and house & $1500-1799,2400-2599,2840-2844,3200-3299$ & 86 & 3.5 \\
\hline $7=$ electric & $3661-3699$ & 161 & 6.6 \\
\hline $8=$ entertainment & $7000-7369,7400-7999$ & 93 & 3.8 \\
\hline $9=$ finance & $6000-6799$ & 190 & 7.8 \\
\hline $10=$ food and tobacco & $2000-2199$ & 69 & 2.8 \\
\hline $11=$ health, education and law & $8000-9999$ & 93 & 3.8 \\
\hline $12=$ machinery & $3510-3569,3580-3652$ & 138 & 5.6 \\
\hline $13=$ medical, photo and other & $3841-3999$ & 81 & 3.3 \\
\hline $14=$ paper and publish & $2600-2673,2711-2780$ & 81 & 3.3 \\
\hline $15=$ petroleum and refinery & $1220-1389,2911-2999$ & 87 & 3.6 \\
\hline $16=$ retail and wholesale & $5000-5999$ & 306 & 12.5 \\
\hline $17=$ steel & $3300-3496$ & 102 & 4.2 \\
\hline $18=$ textile & $2200-2399$ & 34 & 1.4 \\
\hline $19=$ transportation & $4011-4799$ & 61 & 2.5 \\
\hline $20=$ utility & $4911-4991$ & 160 & 6.5 \\
\hline $21=$ others & $2833-2836,2851-2891$ & 115 & 4.7 \\
\hline Total CEOs & & 2448 & 100.0 \\
\hline
\end{tabular}

\section{Analysis of Regression Effects}

To test hypotheses 1 through 8 , a hierarchical regression was employed. The first step was to enter the control variables (tenure, age, duality and gender) into the equations. The second step was to enter the various independent variables of international diversification, industrial diversification, investment opportunities, and firm size, firm performance, and stock ownership. The significance of the change in $R^{2}$ from steps 1 to 2 provides a test of whether the set of predictor variables in step 2 explain a significant amount of the variance in CEO salary beyond that already explained by the control variables. 
Regression Model 1: CEO Salary

Table 5 reports the results of the hierarchical regression CEO salary full model, which examined hypotheses $H_{1}, H_{2}, H_{3}, H_{4}, H_{5}$. Table 6 reports the results of the estimated model, which included control variables plus the main effects of independent variables used to examine hypotheses $H_{1}, H_{2}, H_{3}, H_{4}, H_{5}$.

Hypothesis $H_{1}$ : International diversification is positively associated with CEO salary.

Hypothesis $\mathrm{H}_{2}$ : Industrial diversification is positively associated with CEO salary.

Hypothesis $H_{3}$ : Market-based performance is positively associated with CEO salary.

Hypothesis $\mathrm{H}_{4}$ : Accounting-based performance is positively associated with CEO salary.

Hypothesis $H_{5}$ :CEO salary is better predicted by accounting-based performance measures than by market-based performance measures.

To test the relationship between the seven independent variables as a whole and CEO salary, a hierarchical regression model was created by entering the control variables in step 1 and the five independent variables in step 2 as discussed above. These are shown in Table 5 and results of the regression are shown in Table 6. Standardized regression weights (beta) are reported for ease in comparing the strength of the relationship between CEO salary and the various predictor variables in the regression model. In total, as indicated by the significant overall $\mathrm{F}$ score (212.387, $\mathrm{p}<.001)$, the total set of predictor variables was significantly related to CEO salary. In addition, the regression explained $49.0 \%$ (adjusted $R^{2}=.488$ ) of the CEO salary.

For hypothesis $H_{1}$ : International diversification is positively associated with CEO salary. The results of international diversification $(\beta=.042, t=2.713, \mathrm{p}<.01)$ show that there is a positive significant relationship between international diversification and CEO salary. Thus, the results support hypothesis $\boldsymbol{H}_{1}$ that international diversification is related to CEO salary. The results demonstrate that the higher the degree of international diversification, the higher the salary paid to CEOs.

For hypothesis $\mathrm{H}_{2}$ : Industrial diversification is positively associated with CEO salary. The results of industrial diversification ( $\beta=.067, t=4.127, \mathrm{p}<.001$ ) shows a positive significant relationship between industrial diversification and CEO salary. Thus, the results support the hypothesis that Industrial diversification will be related to CEO salary. The results demonstrate that the higher the degree of Industrial diversification, the higher the CEO salary paid to CEOs.

For the hypothesis $\mathrm{H}_{3}$ : Market-based performance is positively associated with CEO salary. The marketbased performance analysis ( $\beta=.047, t=3.254, \mathrm{p}<.001$ ) shows that market-based performance is positively and significantly associated with CEO salary. Thus, the results support hypothesis $\boldsymbol{H}_{3}$ that industrial diversification is positively associated with CEO salary. The results demonstrate that CEOs in higher market-based performance firms receive higher CEO salary than CEOs in lower market-based performance firms.

For the hypothesis $H_{4}$ : Accounting-based performance is positively associated with CEO salary. The results of accounting-based performance ( $\beta=.234, t=10.189, \mathrm{p}<.001$ ) show that there is a positive significant relationship between accounting-based performance and CEO salary. Thus, the results support hypothesis $H_{4}$ that accounting-based performance is positively associated with CEO salary. The results demonstrate that CEOs in higher earnings firms, receive higher CEO salary than CEOs in lower earnings firms. 
Hypothesis $\mathrm{H}_{5}$ states that CEO salary is better predicted by accounting-based performance measures than by market-based performance measures. As the regression analysis in Table 6 shows, there is support for hypothesis $\boldsymbol{H}_{5}$. In the hierarchical regression analysis (Table 5), accounting-based performance is a significant predictor of CEO salary $(.234, \mathrm{p}<.001)$ and adds incrementally to the adjusted R-square. Market-based performance is also a significant predictor of CEO salary $(.047, \mathrm{p}<.001)$. In contrast to the coefficient of accounting-based performance, CEO salary is better predicted by accounting-based performance measures $(\beta=.234)$ than by market-based performance measures $(\beta=.047)$. These results are consistent with Singh and Agarwal (2002) who found that accounting-based performance has a significant impact on short-term compensation. These results also are consistent with Pavlik, Scott, and Tiessen (1993) who found that accounting performance is more important than stock performance with respect to cash compensation, while stock return appears to be more important when the compensation includes shareholding and options. Taken together, these results provide support for hypotheses $H_{1}$, $\mathrm{H}_{2} \mathrm{H}_{3}, \mathrm{H}_{4}, \mathrm{H}_{5}$.

\section{ANALYSES AND RESULT}

This study examines the influence of international diversification, industrial diversification and firm performance on CEO salary. Table 6 above presents the regression results for model 1 analysis for CEO salary.

\section{Effect of CEO salary}

\section{International diversification (Hypothesis 1)}

The results support hypothesis $H_{1}$ that international diversification is positively associated with CEO salary. The results demonstrate that the higher the degree of international diversification, the higher the CEO salary paid to CEOs. Duru and Reeb (2002) found that there is a positive relationship between international diversification and total compensation and incentive compensation. This study extends their research to explore whether international diversification is positively associated with CEO salary. This study supports their findings and provides additional evidence that international diversification is positively associated with CEO salary.

\section{Industrial diversification (Hypothesis 2)}

The results show that there is a positive significant relationship between industrial diversification and CEO salary. Since hypothesis $\mathrm{H}_{2}$ predicted that the sign was opposite, thus, no support was provided for hypothesis $\mathrm{H}_{2}$. This result is inconsistent with Duru and Reeb's (2002) finding that there is a negative relationship between industrial diversification and total compensation. However, this study extends previous research in more detail to explore whether industrial diversification is associated with CEO salary.

\section{Market-based performance (Hypothesis 3)}

The results support hypothesis $\boldsymbol{H}_{3}$ that industrial diversification is positively associated with CEO salary. The results demonstrated that the higher the stock return earnings, the higher the CEO salary. Singh and Agarwal, (2002) and Cyert, Kang and Kumar (2002) did not find a significant relationship between market-based performance and CEO salary. Unlike earlier studies, this study controlled for omitted variables, including stock ownership, investment opportunity, gender, age, duality, and tenure. This improved methodology enabled this study to observe salary pay where previous studies found no relation between market-based performance and CEO salary. 
Table 5

Hierarchical Regression of CEO salary on Corporate Diversification and Firm Performance

(Hypothesis $H_{1 b A}, H_{2 b A}, H_{3 b A}, H_{4 b A}, H_{5 b A}$ ) Model 1

$S A L A R Y_{t, i}=b_{0}+b_{1} I N T D+b_{2} I N D D+b_{3} R E T+b_{4} A C E+b_{5} I O+b_{6} S I Z E+b_{7} O W N+b_{8}$ Tenure $+b_{9}$ Age $+b_{10}$ Duality $+b_{11}$ Gender $+\varepsilon_{t, i}$

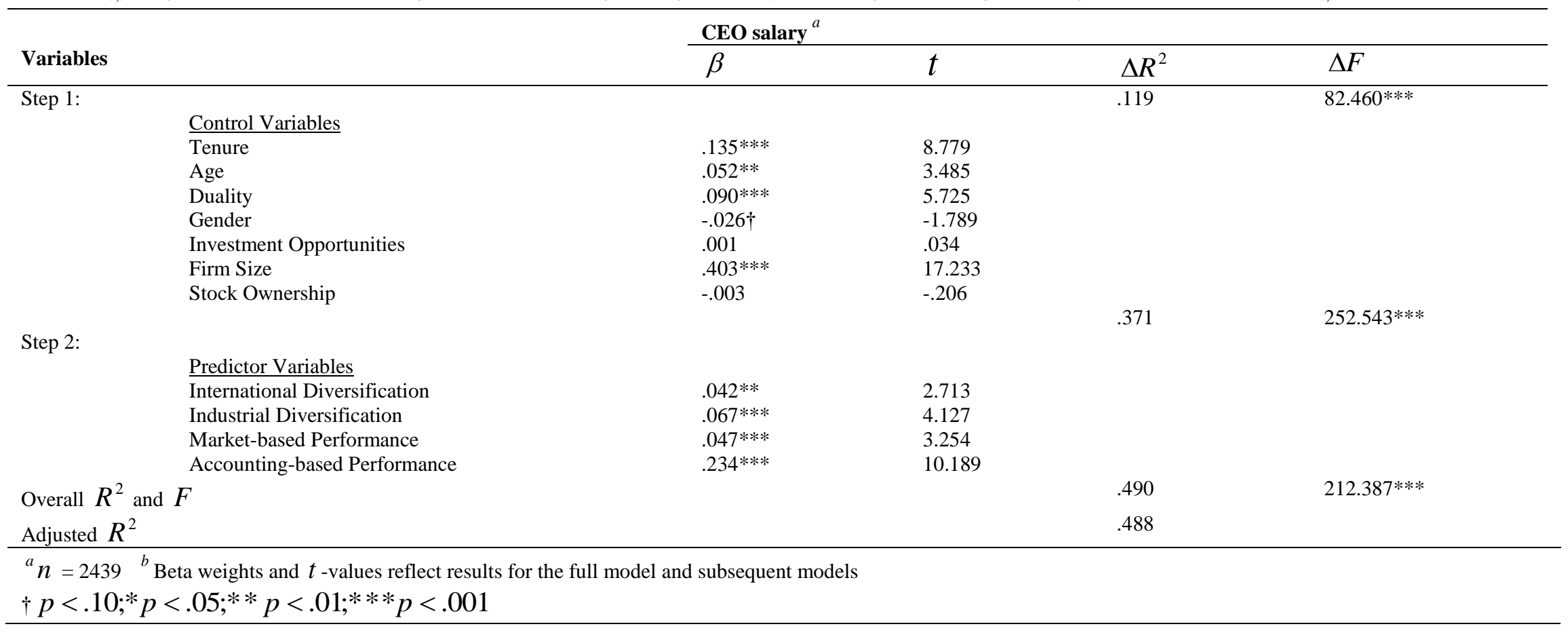


Table 6

Results of Regression Equations Model 1 Analysis for CEO salary

$S A L A R Y_{t, i}=b_{0}+b_{1} I N T D+b_{2} I N D D+b_{3} R E T+b_{4} A C E+b_{5} I O+b_{6} S I Z E+$

$b_{7} \mathrm{OWN}+b_{8}$ Tenure $+b_{9}$ Age $+b_{10}$ Duality $+b_{11}$ Gender $+\varepsilon_{t, i}$

\begin{tabular}{|c|c|}
\hline Variable & Model 1 \\
\hline$b_{1}$ International Diversification $(I N T D)$ & $\begin{array}{l}.042 * * \\
(2.713)\end{array}$ \\
\hline$b_{2}$ Industry Diversification ( INDD) & $\begin{array}{l}.067 * * * \\
(4.127)\end{array}$ \\
\hline$b_{3}$ Market based Performance ( $R E T$ ) & $\begin{array}{l}.047 * * * \\
(3.254)\end{array}$ \\
\hline$b_{4}$ Accounting based Performance $(A C E)$ & $\begin{array}{l}.234 * * * \\
(10.189)\end{array}$ \\
\hline$b_{5}$ Investment Opportunities $(I O)$ & $\begin{array}{l}.001 \\
(.034)\end{array}$ \\
\hline$b_{6}$ Firm Size $(S I Z E)$ & $\begin{array}{l}.403 * * * \\
(17.233)\end{array}$ \\
\hline$b_{7}$ Stock Ownership $(O W N)$ & $\begin{array}{l}-.003 \\
(-.206)\end{array}$ \\
\hline$b_{8}$ Tenure & $\begin{array}{l}.135 * * \\
(8.779)\end{array}$ \\
\hline$b_{9}$ Age & $\begin{array}{l}.052 * * \\
(3.485)\end{array}$ \\
\hline$b_{10}$ Duality & $\begin{array}{l}.090^{* * *} \\
(5.725)\end{array}$ \\
\hline$b_{11}$ Gender & $\begin{array}{l}-.026 \dagger \\
(-1.789)\end{array}$ \\
\hline Adjusted $R^{2}$ & .490 \\
\hline Change in adjusted $R^{2}$ & $.371^{* * *}$ \\
\hline \multicolumn{2}{|c|}{$\begin{array}{l}\text { Note. }{ }^{a} n=2439{ }^{b} \text { Beta weights and } t \text {-values reflect results for the full model } \dagger \\
\quad p<.10 ;{ }^{*} p<.05 ; * * p<.01 ; * * p<.001\end{array}$} \\
\hline
\end{tabular}

Accounting-based performance (Hypothesis 4)

The results support hypothesis $\mathrm{H}_{4}$ that accounting-based performance is positively associated with CEO salary. The results demonstrate that firms with higher earnings will pay higher CEO salaries. Singh and Agarwal (2002) found that there is no significant relationship between accounting-based performance and CEO compensation. Cyert, Kang, Kumar (2002) found that there is a negative relationship between accounting-based performance and CEO compensation. However, the results are ambiguous. This study found that accounting-based performance is strong positively related to CEO salary, which is inconsistent with previous research. 
Market-based performance, Accounting-based performance and CEO salary(Hypothesis 5)

For Hypothesis 5: CEO salary will be better predicted by accounting-based performance measures than by market-based performance measures. The results are consistent with Singh and Agarwal (2002) who found that accounting-based performance has a greater impact on short-term compensation. These results also are consistent with Pavlik, Scott, and Tiessen (1993) who found that accounting performance is more important than stock performance with respect to cash compensation, while stock return appears to be more important when the compensation includes shareholding and options.

\section{CONCLUSIONS}

Singh and Agarwal, (2002); Cyert, Kang and Kumar (2002) found no evidence that market-based performance is associated with CEO compensation. Unlike earlier studies, this study enhanced the methodology by controls for omitted variables such as stock ownership, investment opportunity and this enhanced methodology enables the study to observe salary where previous studies found no relation between market-based performance and CEO salary.

Duru and Reeb(2002) found a positive relationship between international diversification and total compensation and incentive compensation. This study extends their study to examine in more depth whether international diversification is related to fixed CEO salary. A review of the literature indicates that this is the first study to examine and confirm that there is a positive significant relationship between international diversification and CEO salary.

In conclusion, the study examined CEO salary for 2448 CEOs between 1997 and 2002. Based on agency and expectancy theories, the study shows that the higher the degree of international diversification, industrial diversification, stock return performance, and accounting earnings performance, the more the CEO receives in fixed CEO salary. In addition, this study finds that CEO salary is better predicted by accounting performance than by stock return performance.

\section{AUTHOR INFORMATION}

Dr. Hwei (Wendy) C. Wang, CPA joined the University of Maryland Eastern Shore in August 2010 as an Associate Professor in the Department of Business, Management and Accounting. Previously, Dr. Wang taught at Alabama A\&M University from August 2005 to August 2010 as Assistant Professor of Accounting in the School of Business. She earned an MBA with dual majors in Professional Accounting and Finance from California State University at San Bernardino and DBA in Accounting from Nova Southeastern University. Her current research interests are centered on Corporate Governance, Executive Compensation, Corporate Diversification, Auditing, and Detecting Fraudulent Financial Reporting. Dr. Wang has six journal publications and ten of national, regional and international of American Accounting Association conference proceedings. E-mail: wwang@umes.edu (Corresponding author)

Dr. Howard Lawrence, CPA, CMA joined the University of Mississippi in 2005. Dr. Lawrence previously taught at Christian Brothers University for 21 years. He earned his Bachelor's in Mechanical Engineering from Christian Brothers University, his MBA from the University of Memphis, and his PhD from the University of Mississippi. Dr. Lawrence's current research interests are in the fields of Corporate Governance and Forensic Accounting. Dr. Lawrence has numerous publications in such journals as Advances in Accounting Behavioral Research, Journal of Accounting and Finance Research, and the Journal of Accounting and Corporate Governance. E-mail: umaccy@olemiss.edu

Dr. Chia-Hui Chen is an Associate Professor at Department of Accounting, College of Management, Providence University. Dr. Chen has taught at Providence University since January 2003. She earned M.S. degree with major in Accounting from Long Island University at C. W. Post, and earned D.B.A. degree with major in Accounting from Nova Southeastern University. Her research interests focus on earnings management, issues on international accounting standards, corporate governance, issues on auditing (i.e., auditing quality and detection of fraudulent 
financial reporting). Dr. Chen has five journal articles published, and has seven manuscripts accepted and published by Annual and Regional American Accounting Association. E-mail: chchen2@pu.edu.tw

\section{REFERENCES}

1. Baber, W. R., Janakiraman, S. N., and Kang, S. (1996). Investment opportunities and the structure of executive compensation. Journal of Accounting and Economics, 21, 297-318.

2. Balkin, D. B., Markman, G. D., and Gomez-Mejia, L. R. (2000). Is CEO pay in high-technology firms related to innovation? The Academy of Management Journal, 43(6), 1118-1129.

3. Barbezat, D. A., and Hughes, J. W. (1990). Se discrimination in labor markets: The Role of statistical evidence. American Economic Review, 80(1), 277-86.

4. Baysinger BD, and Hoskisson RE. (1990). The composition of the board of directors and strategic control: Effects of corporate strategy. Academy of Management Review, 15, 72-87.

5. Bertrand, M. and Hallo, K.F. (2000). The gender gap in top corporate jobs. Industrial \& Labor Relations Review, 55(1), 3-22.

6. Binder, J. J. (1998). The event study methodology since 1969. Review of Quantitative Finance and Accounting, 11, 111-37.

7. Boyd, B. K. (1994). Board control and CEO compensation. Strategic Management Journal, 15, 335.

8. Bryan, S., Hwang, L. and Lilien, S. (2000). CEO stock-based compensation: An empirical analysis of incentive-intensity, relative mix, and economic determinants. The Journal of Business, 73(4), 661-694.

9. Chung, K. and Charoenwong, C. (1991). Investment options, assets in place, and the risk of stocks. Financial Management, 20(3), 21-34.

10. Collins, M. C., Blackwell, D. W., and Sinkey, J. F. (1995). The relationship between corporate compensation policies and investment opportunities: Empirical evidence for large bank holding companies. Financial Management, 24(3), 40-54.

11. Cooley, Philip L., and Edwards, C. E. (1982). Ownership Effects on Managerial Salaries and Small Business. Financial Management, 11(4), 5-9

12. Cyert, R. M., Kang, S., and Kumar, P. (2002). Corporate governance, takeovers, and top-management compensation: Theory and evidence. Management Science, 48 (4) 453-470.

13. Deckop, J. R. (1988). Determinants of chief executive officer compensation. Industrial and Labor Relations Review, 41, 215-226.

14. Denis, J., Denis, D. K., and Yost, K. (2002). Global diversification, industrial diversification, and firm value. The Journal of Finance, LVII(5), 1951-1979.

15. Duru, A. and Reeb, D. M. (2002). Geographic and industrial corporate diversification: The level and structure of executive compensation. Journal of Accounting, 17(1), 1.

16. Fatemi, A.M. (1984). Shareholder benefits from corporate International diversification. The Journal of Finance, XXXIX, (5), 1325-1344.

17. Finkelstein, S. R. and D'Aveni. A. (1994). CEO Duality as a double-edged sword: How boards of directors balance entrenchment avoidance and unity of command. Academy of Management Journal, 37 (5), 10791108.

18. Finkelstein, S. and Hambrick, D.C. (1996). Strategic leadership: Top executives and their effects on organizations. Minneapolis/St Paul, MN: West Publishing.

19. Gander, J. P. (1997). Gender-based faculty-pay differences in academe: A reduced-form approach. Journal of Labor Research, 18(3), 451-61.

20. Gaver, J.J. and Gaver, K. M. (1993). Additional Evidence on the Association between the investment opportunity set and corporate financing, dividend and compensation policies. Journal of Accounting and Economics, 16(1-3), 125-160.

21. Gaver, J.J. and Gaver, K. M. (1995). Compensation policy and the investment opportunity set. Financial Management, 24(1), 19-33.

22. Grace, E. (2004). Contracting incentives and compensation for property-liability insurer executives. Journal of Risk and Insurance, 71(2), 285-308.

23. Grossman, W. and Hoskisson, R. E. (1998). CEO pay at the crossroads of Wall Street and Main: Toward the strategic design of executive compensation. The Academy of Management Executive, 12(1), 43-58. 
24. Hambrick, D.C. and Mason. P. (1984). Upper echelons: The organization as a reflection of its top managers. Academy of Management Review, 9, 193-206.

25. Hanke, J.E. and Reitsch, A.G. (1994). Understanding business statistics. Boston: Irwin. Hill, C. W. L. and Phan, P. (1991). CEO tenure as a determinant of CEO pay. Academy of Management Journal, 34, 707-717.

26. Hitt, M., and Barr, S. (1989). Managerial selection decision models: Examination of configural cue processing. Journal of Applied Psychology, 74, 53-61.

27. Jensen, M. C., and Murphy, K. J. (1990). Performance pay and top management incentives. Journal of Political Economy, 98, 225-264.

28. Jensen, M. C., Murphy, K. J. (1990). CEO incentives: It's not how much you pay, but how. Harvard Business Review, 68 (3), 138-154.

29. Kim, C., Kim, S.and Pantzalis. (2001). Firm diversification and earnings volatility: An empirical analysis of U.S.--based MNCs. American Business Review., 19(1), 26-39.

30. Lambert, R.A. and Larcker, D. F. (1987). An analysis of the use of accounting and market measures of performance in executive compensation contracts. Journal of Accounting Research, 85-125.

31. Lehn, K., and Poulsen, A. (1989). Free cash flow and stockholder gains in going private transactions. Journal of Finance, 44, 771-789.

32. Lewellen, W. G., Loderer, C., and Martin, K. (1987). Executive compensation and executive incentive problems: An empirical analysis. Journal of Accounting and Economics, 9(3): 287-310.

33. Lippert, R., and Moore, W. (1995). Monitoring versus bonding: shareholder rights and management compensation. Financial Management, 24, (3)5461

34. McWilliams, A. and Siegel, D. (1997). Event studies in management research: Theoretical and empirical issues. Academy of Management Journal, 40, 626-57.

35. Miller, D. J. (1995). CEO salary increases may be rational after all: Referents and contracts in CEO pay. Academy of Management Journal, 38(5), 1361-1386.

36. Mohan, N. and Ruggiero, J. (2003). Compensation differences between male and female CEOs for publicly traded firms: A nonparametric analysis. The Journal of the Operational Research Society, 54(12), 12421248.

37. Murphy, K. J. (1985). Corporate performance and managerial remuneration: An empirical analysis. Journal of Accounting and Economics, 7, 1-42.

38. Myers, S., (1977). Determinants of corporate borrowing. Journal of Financial Economics, 5, 147-175.

39. Newman, H. A., and Bannister, J. W. (1998). Cross-sectional difference in corporate compensation structure. Journal of Managerial Issues, 10, 223-239.

40. Pavlik, E.L., Scott, T. W. and Tiessen, P. (1993). Executive compensation: Issues and research. Journal of Accounting Literature, 12, 131.

41. Platt, H. D. (1987). Determinants of executive compensation: The neoclassical versus concept formulation. Journal of Economic Psychology, 8, 255-272.

42. Ransom, M. R., and Megdal, S. B. (1993). Sex differences in the academic labor market in the affirmative action era. Economics of Education Review, 12(1), 21-43.

43. Redling, E. T. (1981). Myth vs. reality: The relationship between top executive pay and corporate performance. Compensation Review, 4, 16-24.

44. Rosen, S. (1982). Authority, control and the distribution of earnings. Bell Journal of Economics, 13, 311323.

45. Sanders, W. G., and Carpenter, M.A. (1998). Internationalization and firm governance: The roles of CEO compensation, top team composition, and board structure. Academy of Management Journal, 41(2), 158179.

46. Sanders, W. G., Davis-Blake, A., and Fredrickson, J. W. (1995). Prizes with strings attached: Determinants of the structure of CEO compensation. Academy of Management Journal, best papers proceedings, 266271.

47. Singh, P., and Agarwal, N. C. (2002). The effects of firm strategy on the level and structure of executive compensation. Canadian Journal of Administrative Sciences, 19(1), 42-57.

48. Singh, P., and Agarwal, N. C. (2003). Executive compensation: Examining an old issue from new perspectives. Compensation and Benefits Review, 35(2), 48-55.

49. Skinner, D. J. (1993). The investment opportunity set and accounting procedure choice. Journal of Accounting Economics, 16, 407-445. 
50. Smith, C.W., and Watts, R. L. (1992). The investment opportunity set and corporate financing, dividend and compensation policies. Journal of Financial Economics, 32 (3), 263-292.

51. Sridharan, U. C. (1996). CEO influence and executive compensation. The Financial Review, 31, 51-66.

52. Tosi, H. L. and Gomez-Mejia L. R. (1994). CEO compensation monitoring and firm performance. Academy of Management Journal, 37, 1002-1016.

53. Useng, C. J., Wells, D. W., and Lilly, J. D. (2000). CEO influence and executive compensation: Large firms vs. small firms. Managerial Finance, 26(8), 3-13.

54. Vroom, V. H. (1964). Work and motivation. New York: John Wiley and Sons.

55. Wiersema and Bantel. (1992). Top management team demography and corporate strategic change. Academy of Management Journal, 35(1), 91-122.

56. Williams, S. (2003). Gender inequities persist in CEO compensation. Association Management, $55(11), 22$.

57. Young, M. N. and Buchholtz, A. K. (2002). Firm performance and CEO pay: Relational demography as a moderator. Journal of Managerial Issues, 14(3), 296-314.

58. Zajac, E.J., and Westphal, J.W. (1994). The costs and benefits of managerial incentives and monitoring in large U.S. corporations: When is more not better? Strategic Management Journal, 15, 121-142. 
NOTES 